\title{
Two Phase Anaerobic Co Digestion of Tannery Wastewater and Dairy Wastewater: Effect of Operational Parameters on Performance of Hydrolytic-Acidogenic Step
}

\author{
Shifare Berhe ${ }^{1,2, *}$, Seyoum Leta ${ }^{2}$ \\ ${ }^{1}$ Chemistry Department, College of Natural and Computational Sciences, Jigjiga University, Jigjiga, Ethiopia \\ ${ }^{2}$ Center for Environmental Science, College of Natural and Computational Sciences, Addis Ababa University, Addis Ababa, Ethiopia \\ Email address: \\ shifare7@gmail.com (S. Berhe), seyoum.leta@aau.edu.et (S. Leta) \\ ${ }^{*}$ Corresponding author
}

\section{To cite this article:}

Shifare Berhe, Seyoum Leta. Two Phase Anaerobic Co Digestion of Tannery Wastewater and Dairy Wastewater: Effect of Operational Parameters on Performance of Hydrolytic-Acidogenic Step. International Journal of Sustainable and Green Energy.

Vol. 6, No. 1, 2017, pp. 1-9. doi: 10.11648/j.ijrse.20170601.11

Received: December 28, 2016; Accepted: January 7, 2017; Published: February 16, 2017

\begin{abstract}
In this study, optimal working conditions for the hydrolytic-acidogenic step in two stageAnaerobic Sequencing Batch Reactor (ASBR) system during anaerobic co digestion of tannery wastewater (TWW) and dairy wastewater (DWW) were investigated. The study was carried out at laboratory scale digesters with $0.4 \mathrm{~L}$ working volume in semi continuous mode operation under mesophilic temperature $\left(38 \pm 2^{\circ} \mathrm{C}\right)$. Four mixing ratios of substrates $(100: 0,75: 25,50: 50,25: 75)$ at hydraulic retention time (HRT) of 5, 3 and 1days and equivalent organic loading rate (OLR) were examined to assess the effect of each operational parameter on process performance of acidogenic step in the two stageASBR. Based on the result obtained, 50:50 substrate (TWW and DWW) mixing ratio(in terms of COD), 3days HRT and OLR of $3.22 \mathrm{gCOD} / 1 /$ daywere selected as optimum operational conditions for enhanced performance of hydrolytic-acidogenic stage during two stage anaerobic co digestion of the two agro industrial wastes. In addition to this, the degree of acidification was mainly affected by higher OLR and the best result (55.5\%) was achieved in the reactor 50:50 operated at 3days HRT and $2.63 \mathrm{~g} \mathrm{COD/1/day} \mathrm{OLR.} \mathrm{In} \mathrm{general} \mathrm{co}$ digestion of tannery wastewater with dairy wastewater is more important than using tannery wastewater alone for its enhanced performance. This is because of the positive synergistic effects of the co-substrates (dairy wastewater) in terms of wellbalanced nutrients, an appropriate $\mathrm{C}: \mathrm{N}$ ratio and a stable buffering capacity.
\end{abstract}

Keywords: Agro Industrial Waste, Anaerobic co Digestion, Dairy Wastewater, Hydrolytic-Acidogenic Stage,

Process Stability, Process Performance, Tannery Wastewater

\section{Introduction}

Wastewater discharged from tannery industry is highly polluted in terms of biological oxygen demand (BOD), chemical oxygen demand (COD), suspended solids (SS), nitrogen, conductivity, sulphate, sulphide and chromium (Mondal et al., 2005). In most of developing countriestannery effluents are discharged directly into nearby water bodies without any treatment and create emissions of greenhouse gas, water pollution, and hazardous wastes, which potentially disrupt local ecosystems and pose human health risks (Favazzi, 2002).

Presently, Ethiopia's leather industry is in the forefront of the leather sector development within the Eastern and Southern Africa region (UN, 2002). It is one of the highly polluting and growth-oriented industries in Ethiopia and annually all tanneries generate 70,104 tonnes of solid waste and 3,393,600 $\mathrm{m}^{3}$ wastewater in the pre-tanning leather processing stage and dispose into the surrounding environment without proper treatment. Only $10 \%$ of the existing tanning industries treat their wastewater to any degree, while the majority $(90 \%)$ discharges their wastewater into nearby bodies, streams and open land without any kind of treatment. These wastewater contains toxic chemicals 
which had disposed to the surroundings without any treatment posing health hazard to the people leaving nearby and downstream (EEPA, 2003; Seyoum Leta et al., 2003). Therefore, appropriate and economically feasible technology which could manage tannery wastewater converting it into bio energy (biogas) and recycling nutrients in the form of bio fertilizer simultaneously protecting the environmental pollution is urgently needed in the country. Anaerobic digestion (AD) is a good alternative technology which can simultaneously produce bio energy (biogas), reduce environmental pollution and provides a valuable effluent rich in nutrients (bio-slurry) that can be applied on soil as fertilizer to assure food security by boosting agricultural productivity.

One of the challenges and difficulties for anaerobic digestion of tannery wastewater (TWW) is its high alkalinity and low $\mathrm{C} / \mathrm{N}$ ratio which leads to ammonification and increase the $\mathrm{pH}$ subsequently to inhibition of methanogenesis and failure of $\mathrm{AD}$ process. Two-phase AD systems plus codigestion of tannery wastewater with waste streams containing high lipid or fat content such as dairy wastewater have been suggested as viable option for the treatment of such waste.

Dairy industry, like most other agro-industries, generates strong wastewaters characterized by high biological oxygen demand (BOD) and chemical oxygen demand (COD) concentrations representing their high organic content and high $\mathrm{C} / \mathrm{N}$ ratio (Orhon et al., 1993). Anaerobic co digestion of tannery wastewater with dairy wastewater is the viable solution since they have synergetic and antagonistic properties to ensure enhanced process performance and stability of hydrolytic-acidogenic reactor in two-phase $\mathrm{AD}$ system.

Since the process performance of the acidogenic reactor significantly affects the performance and stability of the subsequent methane reactor in the two stage anaerobic digestion process, both the optimumenvironmental and operational parameters influencing the acid-phase digestion should be determined for each particular waste in question. Among the operational parameters, hydraulic retention time (HRT) is an important variable in two stage anaerobic treatment processes (Traverso et al., 2000).

The effects of HRT on anaerobic acidogenesis of different substrates have been previously researched andHRT was found to affect the performance of the acid reactor in the twostage anaerobic digestion of pharmaceutical wastewater (Yalcin et al., 2006), sunflower oil cake (De La Rubia et al., 2009)and olive pomace (Borja et al., 2004). pH is another important variable for providing a stable andmore favourable substrate for the methanogenic step. Severalauthors suggested that the optimal $\mathrm{pH}$ for a better hydrolytic andacidogenic bacteria activity ranges between 5.5 and 6.5 (Bouallagui et al., 2004;Demirer and Chen, 2004). Therefore to increase the efficiency of two phase anaerobic digestion system; it is particularly important to optimize the working conditions such OLR, HRT and substrate mixing ratio within the hydrolytic-acidogenic digester since hydrolysis and acidogenesis is often considered to be the rate limiting fermentation step. The objective of this research work was to evaluate the effect feedstock mixing ratio, OLR and HRT on performance of hydrolytic-acidogenic step of two stage ASBR under mesophilic temperature $\left(38 \pm 2{ }^{\circ} \mathrm{C}\right)$ during anaerobic co digestion of agro industrial wastes(tannery wastewater with dairy wastewater).

\section{Materials and Methods}

\subsection{Agro Industrial Wastes Used as Feedstock Sources}

Samples of tannery wastewater (from general line) used as main substrate during anaerobic co digestion study was collected fromModjo tanning industry, which is located 80 $\mathrm{Km}$ South of Addis Ababa. Modjo tannery is a medium sized leather industry in Ethiopia with annual processing capacity of 844,000 sheepskins and 1,656,000 goat skins (EPA, 2003). The plant is installed near the Modjo River and discharges volumetric effluents which varies between 3,500-5,500 cubic meters per day directly into the river course (Seyoum Leta, 2004). The composite sample were collected in acidified $2 \mathrm{~L}$ polyethylene plastic bottlefrom the general wastewater line which is free of chromiumcarry effluent to the pilot scale agro-industrial wastewater treatment plant developed by Bioinnovative program of East Africa in partnership with Addis Ababa University. Then the samples were taken to Addis Ababa University Center for Environmental Science laboratory and preserved at $4^{\circ} \mathrm{C}$.

Dairy wastewater used as co substrate through the entire study was collected from cleaning of transport lines and equipment between production cycles, cleaning of tank trucks, washing of milk silos and equipment malfunctions or operational errorsof Lame dairy factory located Addis Ababa (Ethiopia) with help of composite sampling technique. Then wastewater samples were stored at $4^{\circ} \mathrm{C}$ in the above specified laboratory prior to analysis and used as reactor feed.

\subsection{Inoculums}

The 1:1 ratio of fresh cow manure and activated sludge consisting of all the essential microbes was used as inoculum in acidogenic reactors. For this purpose cow manure was collected from commercial dairy farm and activated sludge was obtained from Pilot scale Modjo tannery wastewater treatment plant developed by Bio-innovative program of East Africa in partnership with Addis Ababa University.

\subsection{Reactor Design}

Evaluation of acidogenic step in the two stage Anaerobic Sequencing Batch Reactor (ASBR) wascarried with 4 laboratory scale digesterswith the working volume of $0.4 \mathrm{~L}$ and sealed with rubber stoppers. Every reactor had appropriate port at its upper part which were used for feeding, sampling and withdraw effluent for every second day of the feeding. The peristaltic pumps were used to fed,decant or withdraw the feedstock from hydrolytic acidogenic reactor. The digesters were maintained at 
mesophilic temperature $\left(38 \pm 2^{\circ} \mathrm{C}\right)$ using thermostat water bath.

\subsection{Operating Procedures}

This laboratory scale research work was conducted to evaluate acidogenic step in the two stage anaerobic co digestion processof TWW and DWW to find out best working conditions (feedstock mixing ratios (TWW:DWW), OLR and HRT) for enhanced process performance of acidogenic reactors. Details for the operating conditions for the experimental study are shown below in Table 1. After microbial acclimatization of the inoculum tomainsubstrate
(TWW) ratio; acidogenic reactors were fed with different mixing ratios of TWW:DWW (100:0, 75:25, 50:50, 25:75) and operated at HRT of 5, 3 and 1day as well as corresponding OLR as shown in Table 1.

During the experimental work the OLR in all reactors were concomitantly increased with decreasing HRT in order to allow microorganisms to adapt the new environment. Then the effect of mixing proportions of TWW and DWW, OLR and HRT on substrate solubilisation and volatile fatty acids (VFA) production of acidogenic step in two stage anaerobic co digestion process were evaluated during steady state.

Table 1. Operating parameters and conditions of acidogenic reactors during co digestion of agro industrial wastes using two stage ASBR under mesophilic temperature.

\begin{tabular}{|c|c|c|c|c|}
\hline & Operating par & f Acidogenic & & \\
\hline Feedstock & Composition & HRT(days) & OLR(gCOD/L.day) & Flow rate (ml/day) \\
\hline \multirow{12}{*}{$\begin{array}{l}\text { Tannery wastewater } \\
\text { (TWW) and Dairy } \\
\text { wastewater (DWW) }\end{array}$} & \multirow{3}{*}{ 100:0TWW } & 1 & 4.47 & 400 \\
\hline & & 3 & 1.50 & 133 \\
\hline & & 5 & 0.894 & 80 \\
\hline & \multirow{3}{*}{$\begin{array}{l}25: 75 \\
\text { TWW+DWW }\end{array}$} & 1 & 6.02 & 400 \\
\hline & & 3 & 2.01 & 133 \\
\hline & & 5 & 1.21 & 80 \\
\hline & \multirow{3}{*}{$\begin{array}{l}50: 50 \\
\text { TWW+DWW }\end{array}$} & 1 & 8.00 & 400 \\
\hline & & 3 & 2.67 & 133 \\
\hline & & 5 & 1.60 & 80 \\
\hline & \multirow{3}{*}{$\begin{array}{l}25: 75 \\
\text { TWW+DWW }\end{array}$} & 1 & 9.68 & 400 \\
\hline & & 3 & 3.23 & 133 \\
\hline & & 5 & 1.94 & 80 \\
\hline
\end{tabular}

The realization of the steady-state was verified after constant effluent characteristic values (SCOD, TCOD, $\mathrm{NH}_{4}{ }^{+}-$ $\mathrm{N}$ and VFA levels) were achieved for seven consecutive days. Before starting the experiment, all the reactors were sparged using nitrogen gas so as to maintain anaerobic conditions. Acidogenic reactors in two stage ASBR were operated at semi continuous mode (one feed per two days interval) for 60 dayswith $48 \mathrm{~h}$ cycle mode. From the total cycle time; $25 \mathrm{~min}$ was given for filling the feed stock to each reactor, $10 \mathrm{~min}$ for mixing, $21 \mathrm{~h}$ for reaction and $2 \mathrm{hfor}$ settling. The decanting was performed using pump driver PD5206rpm for $25 \mathrm{~min}$ same as filling phase.

\subsection{Analytical Methods}

Analyzing physical and chemical characteristic of the feed stock before and after anaerobic digestion is important to evaluate the performance of anaerobic system. As the result tannery wastewater and dairy wastewater were characterized fortotal and soluble chemical oxygen demand (TCOD, SCOD), totaland volatile suspended solids(TS, VS), $\mathrm{pH}$, kjeldahl nitrogen(TKN), total ammonia nitrogen(TAN) using the standard methods (APHA, 2012). Protein content was estimated by multiplying the organic nitrogen value (TKN subtracted by total ammonia nitrogen by 6.25(Ahn et al., 2006). Samples for soluble chemical oxygen demand (SCOD) and total volatile fatty acid (TVFA) were filtered through glass fiber filter paper $(0.45 \mu \mathrm{m}$ whatman $\mathrm{GF} / \mathrm{C})$.
Total alkalinity and total volatile acid (TVFA) were determined by titration method as described at standard method (APHA, 2012). Fat in the samples were analysed by soxhlet extraction method (APHA, 2012).

Some selected heavy and light metals such as $\mathrm{Cr}, \mathrm{Na}, \mathrm{K}$, $\mathrm{Ca}$ and $\mathrm{Mg}$ in the feedstock were determined after nitric acid/hydrogen peroxide microwave digestion by atomic absorption spectrometer.

\subsection{Calculation (Degree of Acidification)}

The performance of acidogenic reactors during anaerobic digestion of TWW and DWWwere evaluated in terms of degreeof acidification, which have been quantified using the percentageof the initial substrate concentration converted to TVFA (totalVFA). Degree of acidification is a way to measure the degree of success of acid fermentation, representing the amount of solubilized matter converted to VFAs and was calculated as shown below for each of the acidogenic reactorsin order to express the acidification efficiency (Amulya et al., 2014).

$$
\text { Degree of acidification }(\%)=\mathrm{S}_{\mathrm{f}} / \mathrm{S}_{\mathrm{i}} \times 100
$$

Where; $\mathrm{S} i$ : Initial substrate concentration, measured in COD as $\mathrm{mg} / \mathrm{L}, \mathrm{S}_{\mathrm{f}}$ : Produced net VFAs (final - initial), expressed as theoretical equivalents of COD concentrations as $\mathrm{mg} / \mathrm{L}$. The COD equivalents of each VFA: Acetic acid, 1.066; Propionic acid, 1.512; Butyric acid, 1.816; Valeric, 
2.036; Caproic acid, 2.204 (Yilmaz and Demirer, 2007).

\subsection{Statistical Analysis}

In this research work; all sample analyses were carried out at least in triplicates to ensure reproducibility and all the experimental data were statistically evaluated using SigmaPlot software (version 10.0) in order to design graphs and perform the statistical analysis.

\section{Result and Discussion}

\subsection{Substrates Characterization}

Table-3shows the average physico-chemical characteristics of four different mixing ratios of TWW:DWW (100:0, 75:25, $50: 50$ and $25: 75$ ). The $\mathrm{C} / \mathrm{N}$ ratio each mixing ratio of the two substrate were $4.9+0.73,12.9+0.66,21.2+0.59$ and $34.3+0.54$ respectively. The $\mathrm{C} / \mathrm{N}$ of 100:0, 75:25 (tannery wastewater and dairy wastewater) was below the optimum value. This is due low organic content and highest nitrogen content of tannery wastewater. Results in Table 3 also show the $\mathrm{C} / \mathrm{N}$ ratio of 50:50 (tannery wastewater and dairy wastewater) was in agreement with the optimum value reported in different literature. In addition to this the $\mathrm{C} / \mathrm{N}$ ratio of 25:75 (tannery wastewater and dairy wastewater) exceeds the recommended range required for the growth anaerobic bacteria. This indicates that dairy wastewater had high organic content and low nitrogen content.

Table 2. Characteristics of Agro-industrial wastes used for the investigation (After mixing the feedstock).

\begin{tabular}{|c|c|c|c|c|}
\hline \multirow{3}{*}{ Parameters } & \multirow{2}{*}{\multicolumn{4}{|c|}{$\begin{array}{l}\text { Inclusion level of tannery wastewater(TWW) } \\
\text { Dairy(milk processing) wastewater(DWW) }\end{array}$}} \\
\hline & & & & \\
\hline & 100:0 & $75: 25$ & $50: 50$ & $25: 75$ \\
\hline $\mathrm{pH}$ & $8.35 \pm 0.34$ & $7.5 \pm 0.32$ & $7.2+0.62$ & $6.55+0.16$ \\
\hline Total Alkalinity $\left(\mathrm{mg} / \mathrm{l}, \mathrm{CaCO}_{3}\right)$ & $380+0.17$ & $240 \pm 0.60$ & $170 \pm 0.41$ & $105 \pm 0.28$ \\
\hline Volatile Solid(mg/l) & $1210+0.31$ & $1275+0.37$ & $1427+0.90$ & $1686+0.86$ \\
\hline Total COD(mg/l) & $4473+1.83$ & $6014+1.6$ & $7990+2.28$ & $9670+1.45$ \\
\hline $\mathrm{TKN}(\mathrm{mg} / \mathrm{l})$ & $915+0.61$ & $468+0.56$ & $376.5 \pm 0.37$ & $282 \pm 0.42$ \\
\hline Protein (mg/l) & $5718.8+0.31$ & $2925+0.13$ & $2353.1+0.50$ & $1762.5+0.22$ \\
\hline Fat(mg/mg dry weight basis) & $6.5 \pm 0.44$ & $24.6 \pm 0.39$ & $43.1 \pm 0.73$ & $62.4+0.42$ \\
\hline Total Ammonia Nitrogen, $\left(\mathrm{mg} \mathrm{NH}_{4}^{+}-\mathrm{N} / \mathrm{l}\right)$ & $282+0.39$ & $136.9+0.50$ & $97.5 \pm 0.66$ & $50.4+0.23$ \\
\hline $\mathrm{C} / \mathrm{N}$ & $4.9+0.73$ & $12.9 \pm 0.66$ & $21.2+0.59$ & $34.3+0.54$ \\
\hline
\end{tabular}

According the data, it is clearly shown that even though $100 \%$ TWW is high in Nitrogen and alkalinity, increasing the DWW mixing ratio had synergetic effect in balancing $\mathrm{C} / \mathrm{N}$ ratio for enhanced biogas production and methane yield. As shown from the result in Table 3, the $\mathrm{pH}$ values of the wastes mixed with different proportion were $8.35 \pm 0.34,7.5 \pm 0.32$, $7.2+0.62$ and $7.1 \pm 0.16$ and all the values are in favourable $\mathrm{pH}$ range for the growth of fermentative and methanogenic bacteria in anaerobic digestion systems. Furthermore, the concentration of COD increased as the mixed amount of dairy wastewater in the feedstock increased and this might be due to the highest organic matter content of dairy wastewater than tannerywastewater.

\subsection{Effect of Substrate Mixture Ratios and HRT on Hydrolysis and Acidogensis Products}

\subsubsection{Effect on $\mathrm{pH}$}

The change in $\mathrm{pH}$ values of acidogenic reactors during anaerobic co digestion of tannery and dairy wastewater at different operating conditions are shown in Table 3 and Figure1. The initial $\mathrm{pH}$ values of the four mixing ratios of the wastes(TWW: DWW; 100:0, 75:25, 50:50 and 25:75) were in the range of 8.35-6.55 respectively (Table 2). After acidification process, the $\mathrm{pH}$ patterns of the reactors were influenced by the operational conditions such as mixing ratios of TWW and DWW, OLR and HRT. As shown from Figure1 the $\mathrm{pH}$ values of all acidogenic reactors fed with four mixing ratios of the wastes operated at HRT of 5, 3 and 1days and equivalent OLRdecreased untilthe system in reach steady state.

This was likely due to increased amount of acid products obtained during acidogenesis which lead to low operational $\mathrm{pH}$. As observed from Table 3 the steady state average $\mathrm{pH}$ values of acidogenic reactors of 100:0, 75:25, 50:50 and 25:75 were ranged in 7.98-.60, 7.05-6.91, 6.46-5.86 and $5.42-4.90$ respectively. It can be seen from these results, when dairy wastewater proportion increased in the feedstock, the $\mathrm{pH}$ decreases significantly and the variations in $\mathrm{pH}$ were typical due to VFAsproduced from degradation of the organic matter in the feedstockat the acidification phase (Jiwei et al., 2014).

The $\mathrm{pH}$ values (6.46-5.86) observed in acidogenic a reactor of 50:50 (TWW: DWW) operated at HRT of 5, 3 and 1 day and equivalent $\operatorname{OLR}(1.57,2.63,7.50 \mathrm{gCOD} / \mathrm{l} /$ day $)$ were suitable for the growth of acidogenic microorganisms since the optimum $\mathrm{pH}$ for hydrolysis and acidogenesis are in the 
range of 5.5-6.5 (Dobreet al., 2014). Therefore proper $\mathrm{pH}$ equal mixing proportion DWW and TWW. conditions were established in the acidogenic reactor fed with

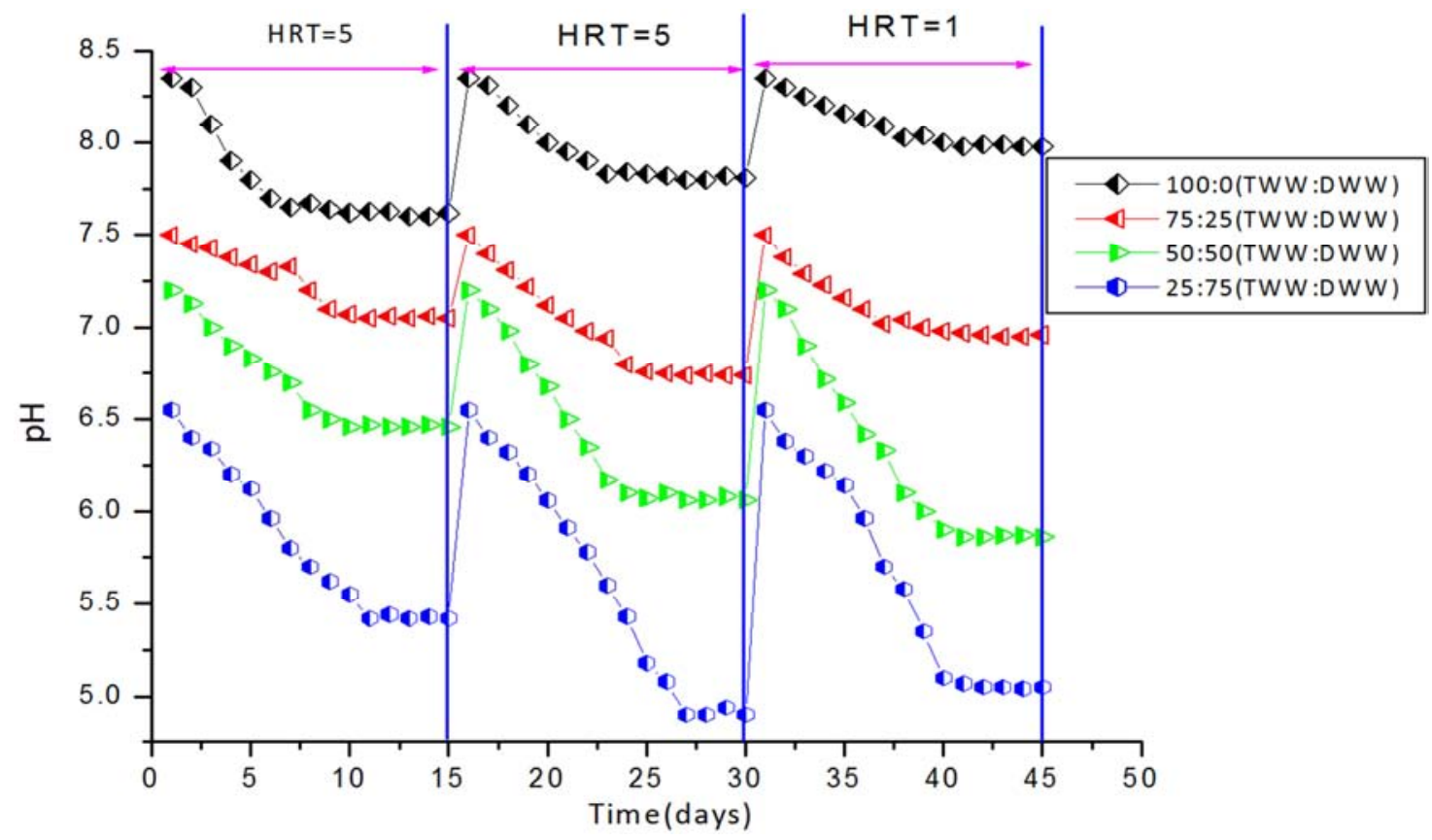

Figure 1. Variation in pH of acidogenic step during anaerobic co digestion of $T W W$ and $D W W$ at differentoperating conditions.

\subsubsection{Effect on SCOD}

The process of anaerobic digestion of organic matter mainly involves three steps, that is, hydrolysis-fermentation, acetogenesis, and methanogenesis (Jianguo et al., 2013). The performance of the hydrolysis and fermentation in acidogenic reactorswereevaluated by the released SCOD, TVFA as well as released $\mathrm{NH}_{4}{ }^{+}-\mathrm{N}$ and average steady state results are shown in Table 3. Figure2 presents the SCOD concentrations in influent and effluent of acidogenic reactors of 100:0, $75: 25,50: 50$ and 25:75 after 15 days of operation. The SCOD concentration in acidogenic reactors increased with increasing proportion of dairy wastewater from $0 \%$ to $75 \%$ (Table 2 and Figure 2). Theaverage SCOD concentrations of acidogenic reactors obtained during steady state were 2.21 , 2.28 and $2.12 \mathrm{~g} \mathrm{COD} / \mathrm{L}(100 \% \mathrm{TWW}$ at HRT of 5, 3 and 1day); 3.40, 3.51 and $3.21 \mathrm{gCOD} / \mathrm{L}(75: 25$ at HRT of 5, 3 and 1day); 4.20, 4.35 and $3.91 \mathrm{gCOD} / \mathrm{L}$ (50:50 at HRT of 5, 3 and 1day) and 5.27, 5.38 and $4.92 \mathrm{gCOD} / \mathrm{L}(25: 75$ at HRT of5, 3 and 1day). Accordingly the highest SCOD concentration was achieved in acidogenic reactor of 25:75for each HRT as compared to results obtained during mono digestion of TWW. This was probably due the degradation of organic matter with in dairy wastewater and accumulation of small molecule organic acids. According to different literature, feed stocks with high concentration of SCOD have high biogas potential (Zhang et al., 2011).

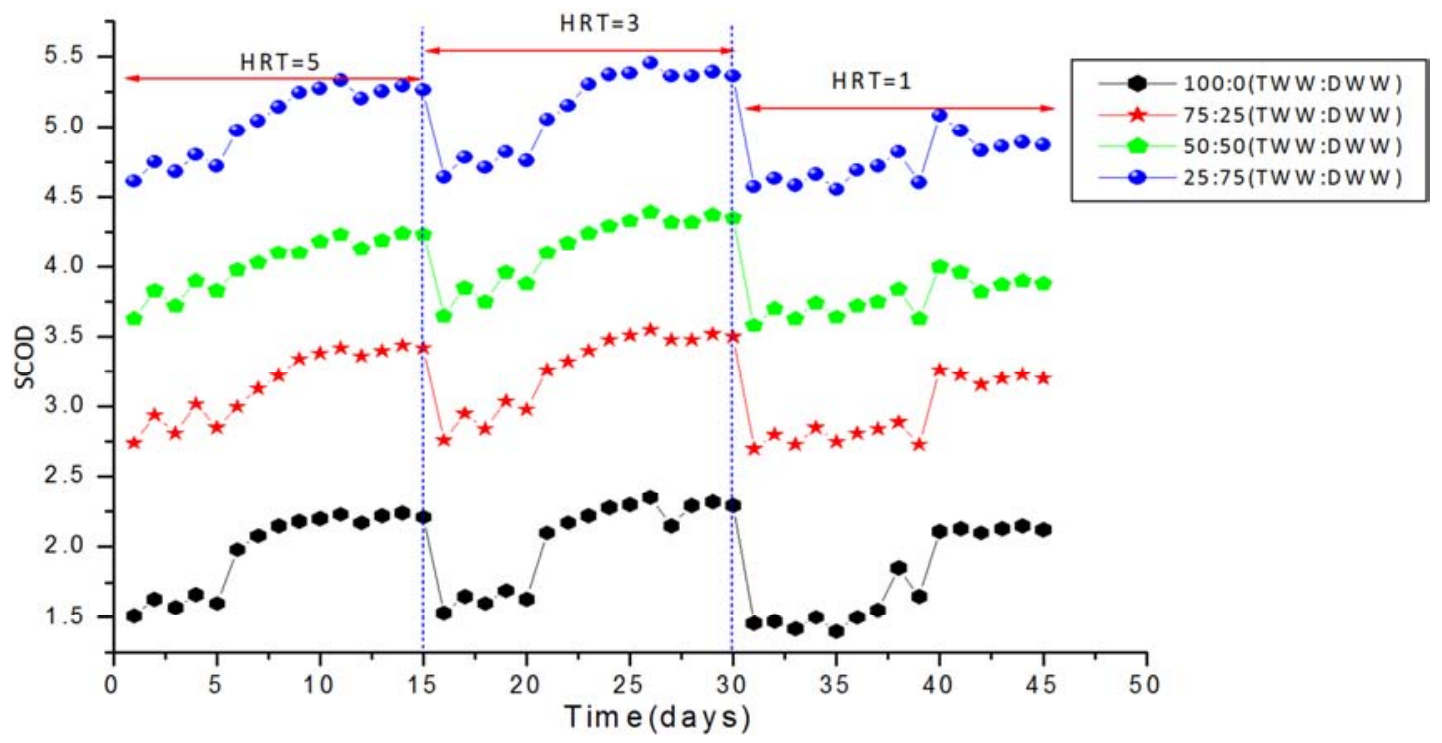

Figure 2. Change in SCOD during anaerobic co digestion of TWW and DWW at various operating conditions. 
Furthermore reactors fed with same mixture ratio of the wastes show variation in SCOD concentration when operating at HRT of 5, 3and 1day and equivalent OLR. As depicted in Figure2 SCOD concentration increases with increasing OLR and decreasing HRT. The best result was obtained in acidogenic reactor of 75:25 which was operated at HRT of 3days and equivalent OLR (3.22 $\mathrm{gCOD} / 1 /$ day). The value significantly reduced when the reactor operated at HRT of 5days and OLR $(9.67 \mathrm{gCOD} / \mathrm{l} / \mathrm{d})$. This might be resulted from the consumption of VFAs which contribute to SCOD concentration. In addition to this the obtained result illustrated in Figure2 show that SCOD concentrations in acidogenic reactors were much higher than the COD converted into corresponding TVFA concentrations indicating that large unknown soluble organic matter was released from hydrolysis and the hydrolysis was likely faster than fermentation.

\subsubsection{Effect on TVFA Production}

Determination of TVFA concentration and composition in hydrolytic-acidogenic reactors during two stage anaerobic digestion process provides information on suitability of the effluent for methanogenic step (Ucisik and Henze, 2008). The average concentration of TVFA in reactors fed with four different proportion of dairy wastewater and tannery wastewater during acidification phase at steady state period of each HRT and OLR are presented in Table 3.

As shown in Table 3 when $100 \%$ TWW was used as a feed in acidogenic reactor and operating at HRT of 5, 3 and 1day and equivalent OLR of $0.906,1.49$ and $4.46 \mathrm{gCOD} / \mathrm{l} /$ day; the TVFA concentrations of $0.98,1.06$ and $0.66 \mathrm{gCH}_{3} \mathrm{COOH} / \mathrm{L}$ respectively were achieved. The concentration of TVFA of the reactor with substrate mixture ratio of $75: 25$ (TWW:DWW) performed at same HRT as above and corresponding $\operatorname{OLR}(1.19,2.0,6.01 \mathrm{gCOD} / \mathrm{l} /$ day $)$ were 2.56 , 2.7 and $1.53 \mathrm{gCH}_{3} \mathrm{COOH} / \mathrm{L}$ respectively.

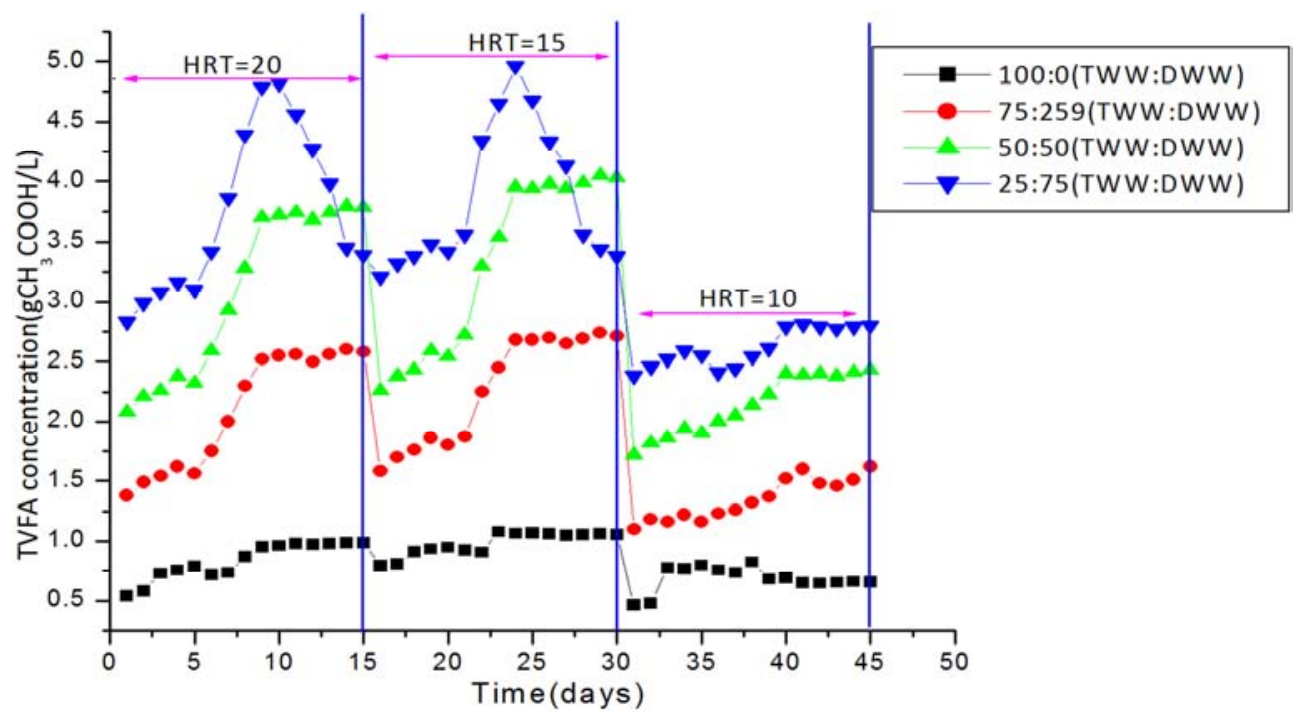

Figure 3. TVFA concentration of acidogenic step during anaerobic co digestion of TWW and DWW at various operating conditions.

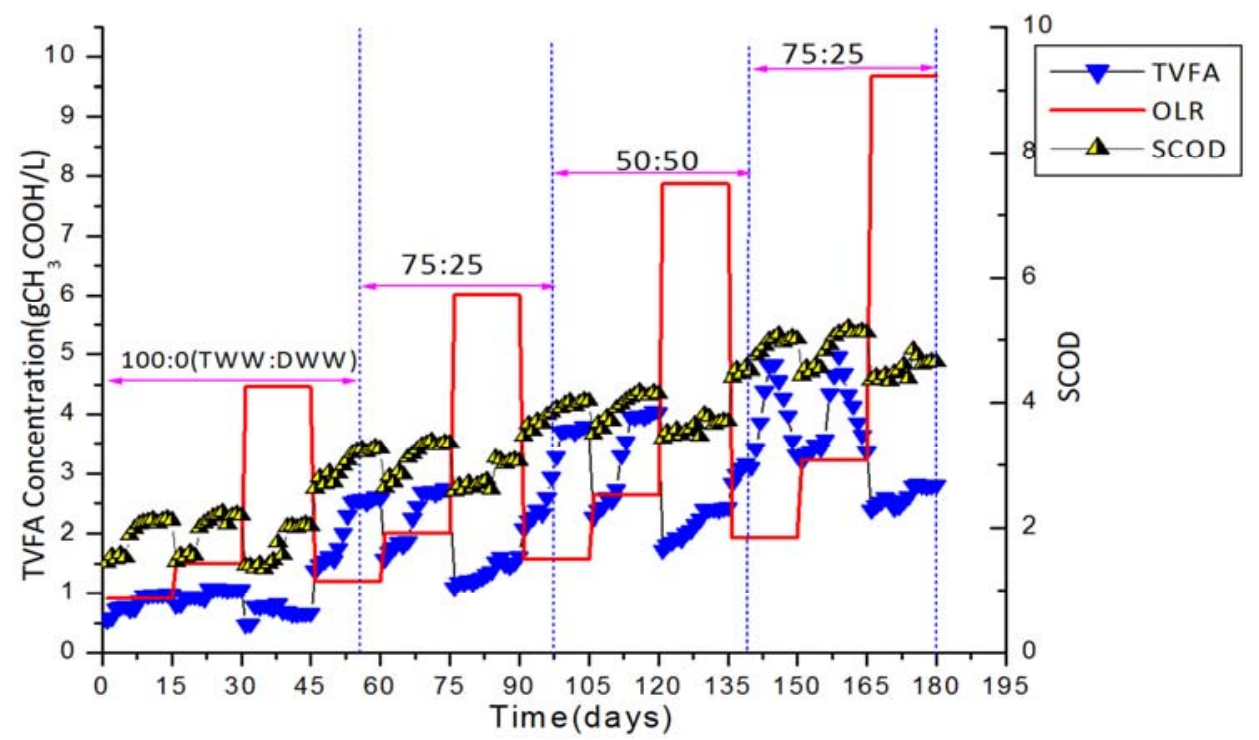

Figure 4. Variation in TVFA concentration of acidogenic step during two stage anaerobic co-digestion of TWW and DWW operated at different OLR and corresponding HRTs. 
For acidogenic reactor of 50:50 operated at HRT of 5, 3 and 1 day and OLR of $1.57,2.63$ and $7.87 \mathrm{gCOD} / 1 / \mathrm{day}$; the TVFA concentrations were $3.74,3.99$ and $2.40 \mathrm{~g}$ $\mathrm{CH}_{3} \mathrm{COOH} / \mathrm{L}$. Furthermore the TVFA concentrations of 4.80 , $4.902 .79 \mathrm{~g} \mathrm{CH}_{3} \mathrm{COOH} / \mathrm{L}$ were achieved in the reactor of 25:75 at the same HRT as above and OLR of 1.93, 3.22, and $9.67 \mathrm{gCOD} / 1 /$ day. These data suggested that TVFA concentrations were increased with the increase of dairy wastewater (DWW) ratios in feedstock and this is maybe due to the large amount of degradable organic matters contained in dairy wastewater compared to tannery waste water. It can be seen from Figure4 that the relative concentration of TVFA was affected by both HRT and OLR. With the same substrate mixture ration, the TVFA increased with increasing OLR(decreasing HRT) and highest TVFA concentration i.e $4.90 \mathrm{~g} \mathrm{CH}_{3} \mathrm{COOH} / \mathrm{L}$ was achieved in acidogenic reactor of 25:75 which was operatedat OLR of $3.22 \mathrm{gCOD} / \mathrm{l} / \mathrm{day}$ and HRT of 3 days (Figure 3 and Figure 4). Similar trend was observed regarding SCOD (Figure 4).

As illustrated in Figure 3 and Figure 4; significant decrease in VFA concentration was observed when HRT decreased from 3 to 1 days and this is probably due to the wash out of part of the hydrolytic-acidogenic consortium during the experimental study (Jianguo et al., 2013). The observed phenomena for decreasing concentration of TVFA with increasing theOLR in the present study is in agreement with the finding obtained by Lim et al. (2008).

Although a higher concentration of VFAs was achieved in acidogenic reactor $25: 75$ at an OLR of $3.22 \mathrm{~g} \mathrm{COD} / 1 /$ day; the high OLR leads to the rapid decrease of VFAs concentration after 10 days of operation and diminished the performance of the reactor.

The $\mathrm{pH}$ values recorded in this reactor at HRT of 5, 3 and 1day and OLR of $1.93,3.22$ and $9.67 \mathrm{~g} \mathrm{COD/1/day} \mathrm{were}$ ranged in 5.42-4.90 which are below the optimum $\mathrm{pH}$ value (5.5-6.5) required for acidogenic microorganism (Dobre et al., 2014). Therefore substrate mixture ratio of 50:50 at OLR $2.63 \mathrm{~g} \mathrm{COD} / / /$ day and equivalent HRT of 3 days are suitable for optimum VFA production.

\subsubsection{Effect on Release of $\mathrm{NH}_{4}{ }^{+}-\mathrm{N}$}

The $\mathrm{NH}_{4}^{+}-\mathrm{N}$ produced during anaerobic hydrolysis of nitrogenous compounds mostly in the form of proteins, which were hydrolyzed into amino acids and further degraded into ammonia. It has significant role in microbial growth and increasing the buffering capacity of anaerobic digestion process (Garcia-Peña et al., 2011). The steady state average $\mathrm{NH}_{4}{ }^{+}-\mathrm{N}$ concentration during two stage anaerobic co digestion of TWW and DWW at various operating conditions is presented in Table 3. The highest steady state average $\mathrm{NH}_{4}{ }^{+}-\mathrm{N}$ concentration $(369.8 \mathrm{mg} / \mathrm{L})$ was obtained in acidogenicrectors fed with $100 \% \mathrm{TWW}$ which was operated at HRT of 3daywhereas lowest value i.e $66.3 \mathrm{mg} / \mathrm{L}$ was recorded in the reactor of 25:75(TWW:DWW) performed at HRT of 1day. The reason for high concentration of $\mathrm{NH}_{4}{ }^{+}-\mathrm{N}$ in the reactor with $100 \% \mathrm{TWW}$ and this is likely due to the low nitrogen content in dairy wastewater as compared to in tannery wastewater.

It can be conclude that the obtainedconcentrations of ammonia in the present studywere never in a range that could adversely affect the performance and stability of the anaerobic acidogenic reactors of $75: 25,50: 50,25: 75$ throughout the experimental study except the value achieved in the reactor feed with $100 \% \mathrm{TWW}$.

Generally, mixing proportion of substrates has an effect on production and accumulation of hydrolysis and acidification products (TVFA, SCOD and $\mathrm{NH}_{4}{ }^{+}-\mathrm{N}$ ) during acidification phase.

Table 3. Steady state average performance of acidogenic reactors at different substrate mixing ratios and organic loading rates as well at different HRTs.

\begin{tabular}{|c|c|c|c|c|c|c|c|c|c|c|c|c|}
\hline \multirow{2}{*}{ Parameters } & \multicolumn{12}{|c|}{ Mixture ratios of Tannery wastewater and Dairy wastewater(TWW:DWW) } \\
\hline & $100: 0$ & 75:25 & 50:50 & 25:75 & $100: 0$ & 75:25 & $50: 50$ & $25: 75$ & $100: 0$ & $75: 25$ & 50:50 & 25:75 \\
\hline Inlet $\mathrm{TCOD}(\mathrm{gCOD} / \mathrm{L})$ & 4.46 & 6.01 & 7.99 & 9.67 & 4.46 & 6.01 & 7.99 & 9.67 & 4.46 & 6.01 & 7.99 & 9.67 \\
\hline Inlet $\mathrm{SCOD}(\mathrm{gCOD} / \mathrm{L})$ & 1.64 & 2.52 & 2.88 & 3.24 & 1.64 & 2.52 & 2.88 & 3.24 & 1.64 & 2.52 & 2.88 & 3.24 \\
\hline Inlet VFA $\left(\mathrm{gCH}_{3} \mathrm{COOH} / \mathrm{L}\right)$ & 0.83 & 1.56 & 2.49 & 3.16 & 0.83 & 1.56 & 2.49 & 3.16 & 0.83 & 1.56 & 2.49 & 3.16 \\
\hline Inlet $\mathrm{NH}_{4}^{+}-\mathrm{N}(\mathrm{mg} / \mathrm{L})$ & 282 & 136.9 & 97.5 & 50.4 & 282 & 136.9 & 97.5 & 50.4 & 282 & 136.9 & 97.5 & 50.4 \\
\hline InletpH & 8.35 & 7.50 & 7.20 & 6.55 & 8.35 & 7.50 & 7.20 & 6.55 & 8.35 & 7.50 & 7.20 & 6.55 \\
\hline OLR (gCOD/1/day) & 0.906 & 1.19 & 1.57 & 1.93 & 1.49 & 2.00 & 2.63 & 3.22 & 4.46 & 6.01 & 7.87 & 9.67 \\
\hline HRT(days) & 5 & 5 & 5 & 5 & 3 & 3 & 3 & 3 & 1 & 1 & 1 & 1 \\
\hline Outlet TCOD(gCOD/L) & 4.24 & 5.74 & 7.64 & 9.32 & 4.29 & 5.82 & 7.74 & 9.53 & 4.38 & 5.92 & 7.83 & 9.60 \\
\hline Outlet SCOD (gCOD/L) & 2.21 & 3.40 & 4.20 & 5.27 & 2.28 & 3.51 & 4.35 & 5.38 & 2.12 & 3.21 & 3.91 & 4.92 \\
\hline OutletTVFA $\left(\mathrm{gCH}_{3} \mathrm{COOH} / \mathrm{L}\right)$ & 0.98 & 2.56 & 3.74 & 4.82 & 1.06 & 2.70 & 3.99 & 4.98 & 0.86 & 1.70 & 2.80 & 3.39 \\
\hline Outlet $\mathrm{NH}_{4}^{+}-\mathrm{N}(\mathrm{mg} / \mathrm{L})$ & 345 & 175.6 & 134 & 76.5 & 369.8 & 195 & 148 & 89.4 & 312 & 153 & 114 & 66.3 \\
\hline OutletpH & 7.60 & 7.05 & 6.46 & 5.42 & 7.78 & 6.91 & 6.05 & 5.31 & 7.98 & 6.95 & 5.86 & 4.90 \\
\hline Degree of Acidification (\%) & 9.75 & 42.3 & 46.3 & 54.6 & 14.0 & 45.2 & 55.5 & 59.9 & 2.0 & 5.9 & 11.5 & 7.57 \\
\hline
\end{tabular}

Note: All the values presented in the above table are average values (mean+SD). The highest degree of acidification achieved at acidogenic reactor of 25:75(TWW:DWW) operated at HRT of 5, 3d during9days operation but the value decreased to $11.8 \%$ and $7.9 \%$ after 10 days of operation respectively with decreasing TVFA production. As the result acidogenic reactor of 50:50 which was operated at HRT of 3days suitable for TVFA production. 


\subsection{Degree of Acidification}

The degree of acidification represents the amount of solubilized matter converted to VFA as end products and measured using previously defined relation in Eq. (1). Degree of acidification in acidogenic reactors fed with substrate mixture ratios of 100:0, 75:25, 50:50 and 25:75 which were operated at HRT of 5, 3 and 1day and equivalent OLR are presented in Table 3. These results are also illustrated in Figure 5. As illustrated in Figure5 the degree of acidification achieved in reactor fed with $100 \% \mathrm{TWW}$ performed at HRT of 5, 3 and 1 day and OLR of $0.91,1.49$ and $4.46 \mathrm{~g}$ COD/1/day were $9.75 \%, 14 \%, 2 \%$ respectively. When $75: 25$ substrate mixture ratio was used as a fed in the reactor and operated at
HRT of 5, 3 and 1day, the degree of acidification obtained were $42.3 \%, 45.2 \%$ and $5.9 \%$ respectively. Degree of acidification of $46.3 \%, 55.5 \%$, and $11.5 \%$ were achieved in acidogenic reactor with substrate mixture ratio of 50:50 operated at HRT of 5, 3 and1day, and equivalent OLR.

In acidogenic reactor fed with substrate mixture ratio of 25:75; the highest degree of acidification i.e $59.9 \%$ was obtained for 9 days of experimental operation at HRT of 3 days which leads to low operational $\mathrm{pH}$ value 5.11. In this average $\mathrm{pH}$ value; acidogenic bacteria were inhibited and the lowest degree of acidification (7.9\%) was achieved after the $10^{\text {th }}$ day of operational period.

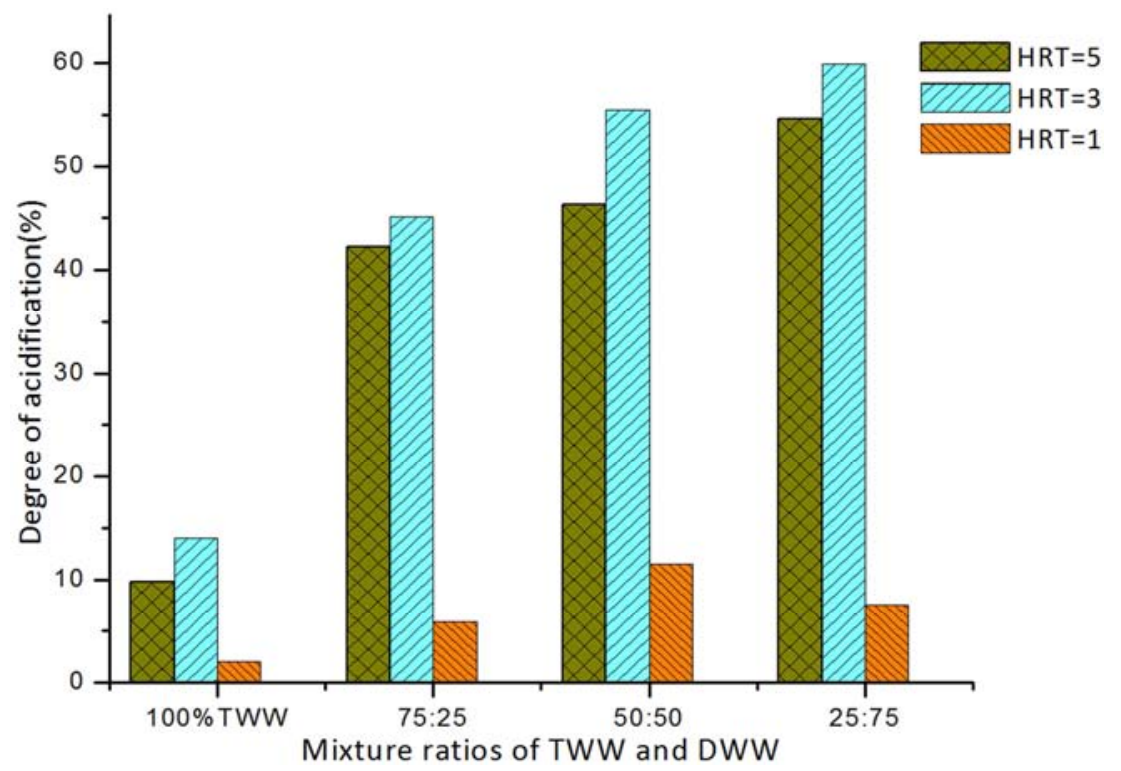

Figure 5. Degree of acidification during anaerobic co digestion $T W W$ and $D W W$ at various working conditions.

In general, it can be concluded from Figure 5the degree of acidification increased with increasing mixing proportions of DWW in the reactor and the best result was obtained in the reactor 50:50. Furthermore reactors with the same substrate mixture ratio also showed variation in degree of acidification at different HRT and OLR. As shown in Table 3 degree of acidification increased with increasing OLR up to $2.63 \mathrm{~g}$ $\mathrm{COD} / / /$ day, the best result $(55.5 \%)$ being achieved in the reactor 50:50 operated at HRT of 3 daysand OLR 2.63 $\mathrm{gCOD} / \mathrm{l} /$ day. However, higher OLR provokes a decrease in degree of acidification. This was probably due to the fact that the acidogenic bacteria could have been affected and inhibited at high organic loading rate (De La Rubia et al., 2009). Similar finding was obtained by Demirel and Yenigun (2004) who reported that at optimum OLR of $9 \mathrm{~g} \mathrm{VS} / \mathrm{L} / \mathrm{d} ; 56 \%$ acidification was achieved in the two-phase anaerobic digestion of liquid effluentswhich is comparable to results of the present study.

\section{Conclusion}

In this study some operation parameters such as OLR,
HRT, and substrate mixing ratios were optimized to establishthebest working conditions for the hydrolyticacidogenic stage during two stage anaerobic co digestion of TWW and DWW under mesophilic temperature $\left(38+2{ }^{\circ} \mathrm{C}\right)$. The performance of the hydrolysis and fermentation in acidogenic reactors were evaluated by the released SCOD, TVFA as well as released $\mathrm{NH}_{4}{ }^{+}-\mathrm{N}$ and average steady state results indicated that the concentration of SCOD, TVFA and $\mathrm{NH}_{4}^{+}-\mathrm{N}$ increased as OLR increased depending on the mixing ratios of TWW and DWW. The TVFA production was shown considerable variation as the mixing proportion of TWW and DWW in thereactor varied. Although a higher concentration of VFAs was achieved in acidogenic reactor fed with substrate mixture ration of 25:75 at an OLR of 3.22 g COD///day; TVFAs concentration after 10 days of operation was diminished due to inhibition of acidogenic consortium.

Furthermore the degree of acidification was found to be increased with increasing proportion of DWW up to $50 \%$ and increasing OLR $2.63 \mathrm{gCOD} / 1 /$ day (decreasing HRT to 3days). However the degree of acidification in the reactor decreased at higher OLR and this was likely due to the inhibition of 
acidogenic bacteria consequently resulting lower TVFA production. In this study, 50:50 substrate (TWW and DWW) mixing ratio(in terms of COD), 3days HRT and OLR of 3.22 $\mathrm{g} \mathrm{COD} / \mathrm{l} /$ daywere selected as an optimum operational condition for enhanced performance and stability of hydrolytic-acidogenic stage during two stage anaerobic co digestion of the two agro industrial wastes under mesophilic temperature. In general co digestion of tannery wastewater with dairy wastewater is more important than using tannery wastewater alone during enhanced acidification products. This is because of the positive synergistic effects of the cosubstrates (dairy wastewater) in terms of well-balanced nutrients, an appropriate $\mathrm{C}: \mathrm{N}$ ratio and a stable buffering capacity.

\section{Acknowledgement}

Authors wish to express their gratitude to Center of Environmental Science College of Natural science Addis Ababa University for providing Laboratory facilities and partial financial support.

\section{References}

[1] Ahn, Y. H. (2006). Sustainable nitrogen elimination biotechnologies: a review. Process Biochemistry. 41(8): 17091721.

[2] Amulya, K., Reddy, M. V., Venkata, M. S. (2014). Acidogenic spent wash valorization through polyhydroxyalkanoate (PHA) synthesis coupled with fermentative biohydrogen production. Bioresour. Technol. 158, 336-342.

[3] APHA, AWWA, WEF, Standard Methods for the Examination of Water and Wastewater, 22nd ed., Washington DC, 2012.

[4] Borja, R., Rincón, B., Raposo, F., Sánchez, E., Martín, A. (2004). Assessment of kinetics parameters for the mesophilic anaerobic degradation of two-phase olive pomace. Int. Biodet. Biodeg. 53, 71-78.

[5] Bouallagui, H., Torrijos, M., Godon, J. J., Moletta, R., Ben Cheikh, R., Touhami, Y., Delgenes, J. P., Hamdi, M. (2004). Two-phases anaerobic digestion of fruits and vegetable wastes: bioreactors performance. Biochem. Eng. J. 21: 193-197.

[6] De La Rubia, M. A., Raposo, F., Rincón, B., Borja, R. (2009). Evaluation of the hydrolytic-acidogenic step of a two-stage mesophilic anaerobic digestion process of sunflower oil cake. Bioresource Technology. 100: 4133-4138.

[7] De La Rubia, M. A., Raposo, F., Rincón, B., Borja, R. (2009). Evaluation of the hydrolytic-acidogenic step of a two-stage mesophilic anaerobic digestion process of sunflower oil cake. Bioresource Technology. 100: 4133-4138.

[8] Demirer, G. N., Chen, S. (2004). Effect of retention time and organic loading rate on anaerobic acidification and biogasification of dairy manure. J. Chem. Technol. Biotechnol. 79: $1381-1387$.

[9] EEPA (2003). Provisional standards for industrial pollution control in Ethiopia. Prepared under the ecologically sustainable industrial development (ESID) project -
US/ETH/99/068/ Ehiopia, EPA/UNIDO, Addis Ababa.

[10] Favazzi, A. (2002) Study of the impact of the main policies and environment protection measures in Africa's leather industry, Paper presentation and study for Meet in Africa. 2002, Retrieved on 15 October 2015 from, http://www.unido.org/fileadmin/import/10203_Studio Favazzi.4.pdf.

[11] Garcia-Peña, E. I., Parameswaran, P., Kang, D. W., CanulChan, M., Krajmalnik-Brown, R. (2011). Anaerobic digestion and co-digestion processes of vegetable and fruit residues: process and microbial ecology. Bioresour. Technol. 102: 94479455 .

[12] Jianguo, J., Yujing, Z., Kaimin, L., Quan, W., Changxiu, G., Menglu, L. (2013). Volatile fatty acids production from food waste: Effects of $\mathrm{pH}$, temperature, and organic loading rate. Bioresource Technology. 143: 525-530.

[13] Jiwei. R., Xufeng, Y., Jie, L., Xuguang, M., Ye, Z., Wanbing, Z., Xiaofen, W., Zongjun, C. (2014). Performance and microbial community dynamics in a two-phase anaerobic codigestion system using cassava dregs and pig manure. Bioresource Technology. 155: 342-351.

[14] Lim, S. J., Kim, B. J., Jeong, C. M., Choi, J. D. R., Ahn, Y. H., Chang, H. N.(2008). Anaerobic organic acid production of food waste in once-a-day feeding and drawing-off bioreactor. Bioresour. Technol. 99 (16), 7866-7874.

[15] Mondal, N. C. Saxena, V. K. Singh, V. S. (2005). Assessment of groundwater pollution due to tannery industries in and around Dindigul, India. Environ. Geol. 48: 149-157.

[16] Orhon, D., Gorgun, E., Germirli, F., Artan, N.(1993). Biological treatability of dairy waste waters. Water Res. 27: 625-33.

[17] Seyoum Leta,FassilAssefa, Gumaelius, L.,Dalhammar, G. (2004). Biological nitrogen and organic matter removal from tannery wastewater in pilot plant operations in Ethiopia. Applied Microbiol.Biotechnol. 66:333-339.

[18] Seyoum Leta, Fassil Assefa, Gunnel, D. (2003). Characterization of tannery wastewater and assessment of downstream pollution profiles along Modjo river in Ethiopia. Ethiopian. J. Biol. Sci. 2(2): 157-168.

[19] Traverso, P., Pavan, P., Bolzonella, D., Innocenti, L., Cecchi, F., Mata-Alvarez, J. (2000). Acidogenic fermentation of source separated mixtures of vegetables and fruits wasted from supermarkets. Biodegradation 11: 407-414.

[20] Ucisik, A. S., Henze, M. (2008). Biological hydrolysis and acidification of sludge under anaerobic conditions: the effect of sludge type and origin on the production and composition of volatile fatty acids. Water Res. 42, 3729-3738.

[21] Yalcin, A. O., Orhan, I., Tom, D., Paul, S., Bahar, K. I. (2006). Determination of optimum operating conditions of an acidification reactor treating a chemical synthesis-based pharmaceutical wastewater. Process Biochemistry. 41: 2258-2263.

[22] Yilmaz, V., Demirer, GN. (2007). Improved anaerobic acidification of unscreened dairy manure. Environ Eng Sci. 25: 309-18.

[23] Zhang, L., Lee, Y., Jahng, D. (2011). Anaerobic co-digestion of food waste and piggery wastewater: Focusing on the role of trace elements. Bioresource Technology. 102: 5048-5059. 